\title{
The Pituitary V3 Vasopressin Receptor and the Corticotroph Phenotype in Ectopic ACTH Syndrome
}

\author{
Yves de Keyzer, Frédéric Lenne, Colette Auzan, ${ }^{\star}$ Sylvie Jégou, ${ }^{\ddagger}$ Patricia René, Hubert Vaudry, ${ }^{\ddagger}$ Jean-Marc Kuhn, ${ }^{\S}$ \\ Jean-Pierre Luton, Eric Clauser, ${ }^{*}$ and Xavier Bertagna \\ INSERM CJF 9208, Institut Cochin de Génétique Moléculaire, Université René Descartes, Paris; *INSERM U-36, Collège de France, \\ Paris; ${ }^{\ddagger}$ INSERM U-413, Mont Saint-Aignan; and ${ }^{\S}$ Groupe Hospitalo-Universitaire de Recherche en Hormonologie, CHU de Rouen, \\ France
}

\begin{abstract}
Ectopic ACTH secretion occurs in highly differentiated and rather indolent tumors like bronchial carcinoids or, in contrast, in various types of aggressive and poorly differentiated neuroendocrine tumors. We explored this phenomenon using the recently cloned human pituitary V3 vasopressin receptor as an alternate molecular marker of the corticotroph phenotype. Expression of V3 receptor, corticotrophin releasing hormone (CRH) receptor, and proopiomelanocortin (POMC) genes was examined in tumors of pituitary and nonpituitary origin. A comparative RT-PCR approach revealed signals for both $\mathrm{V} 3$ receptor and CHR receptor mRNAs in 17 of $18 \mathrm{ACTH}$-secreting pituitary adenomas, and 6 of 6 normal pituitaries; in six growth hormone- or prolactin-secreting adenomas, a very faint $\mathrm{V} 3$ receptor signal was observed in three cases, and CRH receptor signal was undetected in all. Six of eight bronchial carcinoids responsible for the ectopic ACTH syndrome had both POMC and V3 receptor signals as high as those in ACTHsecreting pituitary adenomas; in contrast, no POMC signal and only a very faint $\mathrm{V} 3$ receptor signal were detected in six of eight nonsecreting bronchial carcinoids. Northern blot analysis showed V3 receptor mRNA of identical size in ACTH-secreting bronchial carcinoids and pituitary tumors. Other types of nonpituitary tumors responsible for ectopic ACTH syndrome presented much lower levels of both POMC and V3 receptor gene expression than those found in ACTH-secreting bronchial carcinoids. In contrast with the $\mathrm{V} 3$ receptor, $\mathrm{CRH}$ receptor $\mathrm{mRNA}$ was detected in the majority of neuroendocrine tumors irrespective of their POMC status. These results show that expression of the $\mathrm{V} 3$ receptor gene participates in the corticotroph phenotype. Its striking association with ACTH-secreting bronchial carcinoids defines a subset of nonpituitary tumors in which ectopic POMC gene expression is but one aspect of a wider process of corticotroph cell differentiation, and opens new possibilities of pharmacological investigations and even manipulations of this peculiar ACTH hypersecretory syndrome. $(J$. Clin. Invest. 1996. 97:1311-1318) Key words: Cushing's
\end{abstract}

Address correspondence to Yves de Keyzer, INSERM CJF 9208, Institut Cochin de Génétique Moléculaire, 24 rue du Fg St. Jacques, 75014 Paris, France. Phone: 1-44-41-23-90; FAX: 1-44-41-23-92.

Received for publication 10 July 1995 and accepted in revised form 27 November 1995.

J. Clin. Invest.

(C) The American Society for Clinical Investigation, Inc.

0021-9738/96/03/1311/08 \$2.00

Volume 97, Number 5, March 1996, 1311-1318 syndrome - gene expression - endocrine tumors - proopiomelanocortin $\bullet$ reverse transcription-PCR

\section{Introduction}

Endocrine tumors have a common set of structural and biochemical features which define a general neuroendocrine phenotype: they contain neurosecretory granules and their biochemical correlates, for example chromogranins and 7B2 (1, 2 ), as well as the specific prohormone convertases PC1 and PC2 for the fine processing of their cognate peptide hormone precursors (3). Some of these neuroendocrine tumors have long been recognized as the source of an ever intriguing pathological phenomenon: ectopic hormone production.

The first recognized, one of the most frequent and often clinically devastating of these disorders is the ectopic ACTH syndrome (4). Its principal sources are bronchial neuroendocrine tumors, either the relatively indolent carcinoids or the poorly differentiated highly malignant small cell carcinomas of the lung (SCCL). ${ }^{1}$ An array of other neuroendocrine tumors including pheochromocytomas, medullary thyroid cancer, thymic or pancreatic carcinoids (5) may also ectopically produce ACTH. Gene expression and maturation of proopiomelanocortin (POMC), the polypeptide precursor to ACTH, has been extensively studied (6-11), yet the cascade of events which trigger POMC gene transcription in a nonpituitary tumor remains totally unknown. In absence of evident POMC gene rearrangement, the role of specific or nonspecific trans-activating factors has generally been believed to be primarily involved in this phenomenon (12).

Among all the various tumors which can provoke the ectopic ACTH syndrome, the bronchial carcinoids certainly have a particular clinical presentation and often give rise to diagnostic pitfalls: their small size and their benign course explain their often frustrating occult nature (13-16); in contrast with the admitted autonomous secretory activity of ACTH-secreting nonpituitary tumors $(4,5)$, they occasionally respond, in an apparently aberrant fashion, to classical dynamic tests (corticotrophin releasing hormone $[\mathrm{CRH}]$, dexamethasone, and metyrapone) like pituitary tumors (17). This can lead to the erroneous diagnosis of Cushing's disease and to unwarranted (and ineffective) pituitary surgery and/or radiation therapy $(17,18)$. Therefore, it was tempting to examine these tumors with an alternate marker, different from POMC itself, that would be another molecular link to the corticotroph phenotype.

1. Abbreviations used in this paper: $\mathrm{CRH}$, corticotrophin releasing hormone; GH, growth hormone; GPDH, glyceraldehyde-3-phosphate dehydrogenase; hßend, human $\beta$-endorphin; POMC, proopiomelanocortin; PRL, prolactin; SCCL, small cell carcinoma of the lung. 
The existence of a specific receptor in the pituitary mediating the vasopressin-induced ACTH surge in response to stress has been surmised for many years $(19,20)$. We cloned a cDNA coding for a protein that fulfills the criteria of a likely candidate. The cDNA was obtained from a library made from a pituitary corticotroph adenoma (21). A similar cDNA sequence was almost simultaneously cloned from normal human pituitary (22) and recently from rat pituitary $(23,24)$. The deduced 424-amino acid human protein is only similar to members of the vasopressin/oxytocin receptor family (25-30) and is more similar to the oxytocin receptor than the V1a receptor. Because phylogenetic analysis also showed that this new receptor diverged early from the V1a sequences and presented the closest relationship with the oxytocin receptor, it was designated $\mathrm{V} 3$ rather than V1b (21). This receptor presents the classical seven putative hydrophobic transmembrane domain structure and is coupled to a Gq-like protein, which activates a phospholipase $\mathrm{C}$, but is pharmacologically different from the V1a and V2 receptors $(21,22)$. Prior pharmacological $(31,32)$ and combined immunohistochemical and radioautographic (33) studies, and recent analyses of the tissue distribution of its mRNA in humans $(21,22)$, suggest that the pituitary, and probably the corticotroph cells, are the main sites of its expression. V3 receptor gene expression may thus be a marker of the corticotroph phenotype and may be used to help shed light on the pathophysiological mechanism of the ectopic ACTH syndrome.

Using the molecular tools provided by the recent cloning of the V3 vasopressin receptor, we show indeed a striking association between the expression of this pituitary-specific receptor and the bronchial carcinoids which produced the highest amounts of POMC peptides.

\section{Methods}

Patients. In all patients with the ectopic ACTH syndrome, Cushing's syndrome was diagnosed on the basis of clinical features suggestive of chronic hypercortisolism, increased urinary cortisol excretion, and/or abnormal response to the low dose dexamethasone suppression test (34). In all cases the final diagnosis was eventually confirmed by histological examination and detection of POMC peptide or its mRNA after surgical removal of the causal tumor. Details on the eight bronchial carcinoids (E1-E8) responsible for an ectopic ACTH syndrome are reported in Table I. Responses to vasopressin in vivo were assessed after the intramuscular administration of 10 IU of lysine vasopressin (Sandoz Ltd., Basel, Switzerland) and measurements of plasma ACTH, either by bioassay or radioimmunoassay, and plasma cortisol (35). Patients with pituitary tumors were operated by the transsphenoidal route. All tumors were obtained at surgery, immediately frozen in liquid nitrogen, and stored at $-80^{\circ} \mathrm{C}$ or in liquid nitrogen until processed. Bronchial tumors were diagnosed according to the OMS classification criteria (1981).

Normal human pituitaries were obtained at autopsy, $2-12 \mathrm{~h}$ postmortem, in subjects with no evidence of endocrine disease; they were frozen and stored as indicated. Poly(A) ${ }^{+}$RNA of normal human pituitary was also obtained commercially (CLONTECH, Palo Alto, CA).

Protein extraction. Tissues were extracted in $5 \mathrm{~N}$ acetic acid as described previously (6) for measurement of peptide tissue content. POMC peptides were assayed with a $\mathrm{COOH}$-terminal human $\beta$-endorphin radioimmunoassay (hßend RIA) which cross-reacts as well with the mature peptide, $\beta$-lipotropin, and the unprocessed precursor (36).

RNA extraction. Total RNA was extracted by the guanidium/cesium chloride method as described (37). The concentration was determined by measuring absorbance at $260 \mathrm{~nm}$ and quality was checked by denaturing agarose gel electrophoresis. Poly(A) ${ }^{+}$RNA was isolated with oligo dT dynabeads (Dynal, Inc., Great Neck, NY).

Northern blot analysis. Poly(A) ${ }^{+}$RNAs were denatured by incubation for 15 min with $15 \mathrm{mM} \mathrm{CH}_{3} \mathrm{H}_{\mathrm{g}} \mathrm{OH}$, separated on a $1 \%$ agarose/ 2.2 M formaldehyde gel, and transferred onto a BAS-85 nitrocellulose sheet (Schleicher \& Schuell, Inc., Keene, NH). The membrane was tested for hybridization to a 1.3-kb EcoRI fragment of hV3 receptor using standard techniques (6). The probe, encompassing $5^{\prime}$ untranslated sequence and most of the coding region, was labeled by random priming with $\left[\alpha{ }^{32} \mathrm{P}\right] \mathrm{dCTP}$. After the final wash the blot was autoradiographed using XAR-OMAT film (Kodak) at $-80^{\circ} \mathrm{C}$ with intensifying screens (DuPont, Wilmington, DE).

S1 nuclease protection assay. S1 nuclease protection assays were performed as described (10) with a single-stranded probe of the hu-

Table I. Clinical and Pathological Features in the Eight Patients with ACTH-secreting Bronchial Carcinoids

\begin{tabular}{|c|c|c|c|c|c|c|c|c|}
\hline Patients & Delay for diagnosis & $\begin{array}{c}\text { Treatment(s) } \\
\text { before thoracic surgery }\end{array}$ & Tumor size & Pathology & Tumor spread & $\begin{array}{l}\text { IR-hßend } \\
\text { tissue content }\end{array}$ & $\begin{array}{l}\text { Response to } \\
\text { LVP test }\end{array}$ & $\begin{array}{l}\text { Follow-up } \\
\text { after surgery }\end{array}$ \\
\hline & $y r$ & & $\mathrm{~cm}$ & & & pg/mg tissue & & \\
\hline E1 & 0 & None & 2.0 & Atypical carcinoid & Invasion & 900 & $(-)$ & Died of tumor at $5 \mathrm{yr}$ \\
\hline E2 & 21 & $\begin{array}{l}\text { Bilateral Adx } \\
\text { Pituitary Rx }\end{array}$ & 3.5 & Atypical carcinoid & Node & $1,123,000$ & Not done & $\begin{array}{l}\text { Remanent ACTH } \\
\text { secretion. Alive at } 2 \text { yr }\end{array}$ \\
\hline E3 & 0 & Op'DDD & 1.5 & Atypical carcinoid & Node & 158,000 & Not done & Remission at $2 \mathrm{yr}$ \\
\hline E4 & 3 & Op'DDD & 1.0 & Typical carcinoid & 0 & 433,000 & $(+)$ & Remission at $12 \mathrm{yr}$ \\
\hline \multirow[t]{2}{*}{ E5 } & 20 & Op'DDD & & & & & & \\
\hline & & $\begin{array}{l}\text { Pituitary Rx } \\
\text { Bilateral Adx }\end{array}$ & 2.5 & Typical carcinoid & 0 & $1,922,000$ & Not done & Remission at $8 \mathrm{yr}$ \\
\hline E6 & 6 & Op'DDD & 0.9 & Typical carcinoid & Node & 250,000 & Not done & Remission at $1.5 \mathrm{yr}$ \\
\hline E7 & 13 & $\begin{array}{l}\text { Op'DDD } \\
\text { Pituitary Rx } \\
\text { Pituitary surgery } \\
\text { Bilateral Adx }\end{array}$ & 1.5 & Typical carcinoid & 0 & 758,000 & $(+)$ & Remission at $12 \mathrm{yr}$ \\
\hline E8 & 4 & Op'DDD & 3.0 & Atypical carcinoid & Invasion & 10,500 & Not done & Died at surgery \\
\hline
\end{tabular}

$A d x$, adrenalectomy; $R x$, conventional radiotherapy. 
A

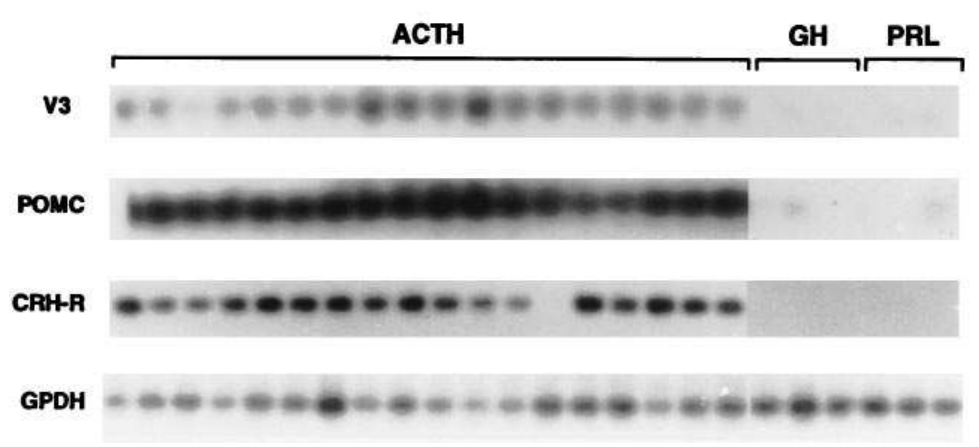

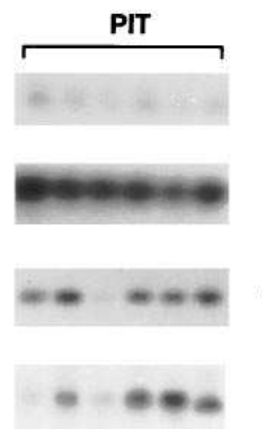

Figure 1. RT-PCR analysis of the expression of the V3 receptor, POMC, $\mathrm{CRH}$ receptor, and GPDH genes in pituV3 itary adenomas $(A)$ and normal pituitaries $(B)$. (A) 18 ACTH-, 3 GH-, and 3 PRL-secreting pituitary adenomas were examined. Equivalent amounts of the same cDNA preparations were used for each PCR, and $20 \%$ of the PCR products were loaded

for each reaction. Exposure times were 4, 1, 2, and $6 \mathrm{~h}$ for V3 receptor, POMC, CRH receptor, and GPDH, respectively. (B) Six normal pituitaries $(P I T)$ were examined in parallel, except for the GPDH reaction, which was performed independently, with reduced cDNA input in two cases (first and third from left), using a newly labeled probe; exposure time was $4 \mathrm{~h}$.

man V3 gene (our unpublished data). The 230 nucleotide (nt) long DNA probe covered $149 \mathrm{nt}$ of exonic sequence and was uniformly labeled with $\left[\alpha-{ }^{32} \mathrm{P}\right] \mathrm{dCTP}$ to a specific activity of $3-5 \times 10^{9} \mathrm{cpm} / \mu \mathrm{g}$. The protected fragments were separated on a $5 \%$ polyacrylamide $7 \mathrm{M}$ urea sequencing gel, and the dried gel was autoradiographed for $3 \mathrm{~d}$ using BioMax films (Kodak) at $-80^{\circ} \mathrm{C}$ with one intensifying screen.

RT-PCR analysis. RT-PCR was performed according to standard protocols (38). Briefly, random primed cDNA was synthesized from $2 \mu \mathrm{g}$ of total RNA with $200 \mathrm{U}$ of MMLV reverse transcriptase (GIBCO BRL, Gaithersburg, MD), and $10 \%$ of the cDNA reaction mixture was directly used for each PCR. Four sets of oligodeoxynucleotides were designed, the numbers in parentheses indicating the positions of the nucleotides from the cap site or the translation initiation codon for the V3 cDNA: CCTGCCTGGAAGATGCCGAGAT (95-116) and TGCTGCGCTGCTGCTGCTGT (368-398) for POMC, TCTCGGTCAGCAGCATCAAC (790-810) and ACCCCCACAGCAGGCAAGG (1056-1074) for the V3 receptor, CATCCGGTGCCTGCGAAACA (475-494) and GGCCCTGGTAGATGGTAGTCG (822-841) for the CRH receptor, and ATCCCATCACCATCTTCCAG (217-236) and AGGGATGATGTTCTGGAGAGC (606-626) for glyceraldehyde-3-phosphate dehydrogenase (GPDH). After 35 cycles of amplification (30 for POMC and 24 for GPDH) of $40 \mathrm{~s}$ at $94^{\circ} \mathrm{C}, 50 \mathrm{~s}$ at $57-62^{\circ} \mathrm{C}$, and $1 \mathrm{~min}$ at $72^{\circ} \mathrm{C}, 20 \%$ of the PCR products were separated on $3 \%$ agarose gel, blotted onto a $\mathrm{Ny}-$ lon membrane (Hybond; Amersham Corp., Arlington Heights, IL), and probed with internal end-labeled oligonucleotides. Filters were exposed as already indicated for Northern blots.

In situ hybridization. Tissue sections $(7 \mu \mathrm{m})$ were realized as described previously (39) and prehybridized for $1 \mathrm{~h}$ at $50^{\circ} \mathrm{C}$ in $50 \%$ formamide, $0.6 \mathrm{M} \mathrm{NaCl}, 10 \mathrm{mM}$ Tris- $\mathrm{HCl}$ (pH 7.5), $1 \times$ Denhardt's, $1 \mathrm{mM}$ EDTA (pH 8.0), $550 \mu \mathrm{g} / \mathrm{ml}$ salmon sperm DNA, and $50 \mu \mathrm{g} / \mathrm{ml}$ yeast transfer RNA. Hybridization was performed in the same conditions for $16-18 \mathrm{~h}$ with $10^{7} \mathrm{cpm} / \mathrm{ml}$ of single-stranded riboprobe, labeled with ${ }^{35} \mathrm{~S}$-UTP. Adjacent sections were hybridized with human POMC (39) or V3 receptor probes. The V3 receptor probe was generated from a plasmid containing a $1.3-\mathrm{kb}$ cDNA fragment encompassing $5^{\prime}$ noncoding sequence and $\sim 800 \mathrm{nt}$ of coding region.

After treatment with RNase A $(50 \mu \mathrm{g} / \mathrm{ml})$ for $1 \mathrm{~h}$ at $37^{\circ} \mathrm{C}$, sections were washed on $0.1 \times \mathrm{SSC}, 15 \mathrm{mM} \beta$-mercaptoethanol, $0.5 \%$ sodium pyrophosphate at $55^{\circ} \mathrm{C}$, dehydrated in graded alcohol, and exposed to $\beta$-Max Hyperfilm (Amersham Corp.) for $14 \mathrm{~d}$.

\section{Results}

Pituitary adenomas. We examined 6 normal pituitaries, 18 ACTH-, 3 growth hormone (GH)-, and 3 prolactin (PRL)- secreting adenomas using a comparative RT-PCR approach to detect POMC, V3 receptor, and $\mathrm{CRH}$ receptor mRNAs in parallel. POMC gene expression was detected as a 304-nt fragment in all normal pituitaries (Fig. $1 B$ ). In the same condi-

BRONCHIAL CARCINOIDS

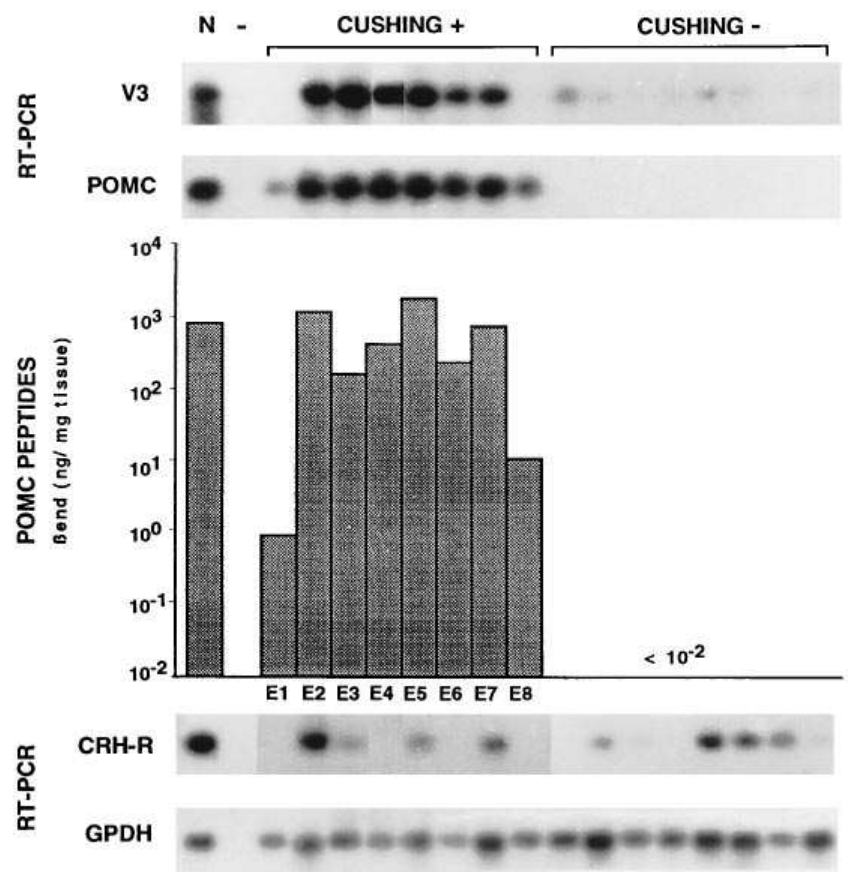

Figure 2. Analysis of the expression of the V3 receptor, POMC, $\mathrm{CRH}$ receptor, and GPDH genes in bronchial carcinoids responsible $(C U S H I N G+)$ or not $(C U S H I N G-)$ for ectopic ACTH syndrome. V3 and CRH receptor gene expressions were studied by RT-PCR only (top and bottom lines, respectively). POMC gene expression was assessed by RT-PCR (top line) and by RIA measurement of the $\beta$-endorphin tissue content (middle). GPDH RT-PCR signals are shown for each tumor sample (bottom line). cDNA from an ACTHsecreting pituitary adenoma responsible for a case of Nelson's syndrome was included as positive control for all four genes $(N)$, and a reverse transcriptase-minus bronchial carcinoid (-) sample was used as a negative control. Exposure times were 5, 3, 2, and $6 \mathrm{~h}$ for V 3 receptor, POMC, CRH receptor, and GPDH, respectively. 
Patient E7
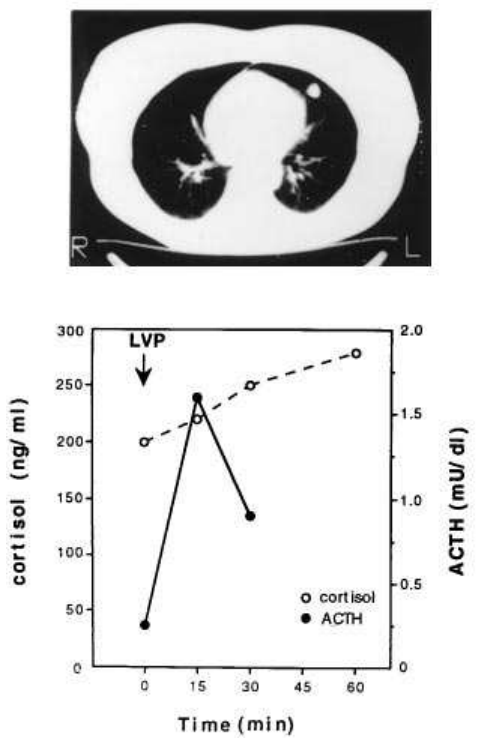

Patient E4
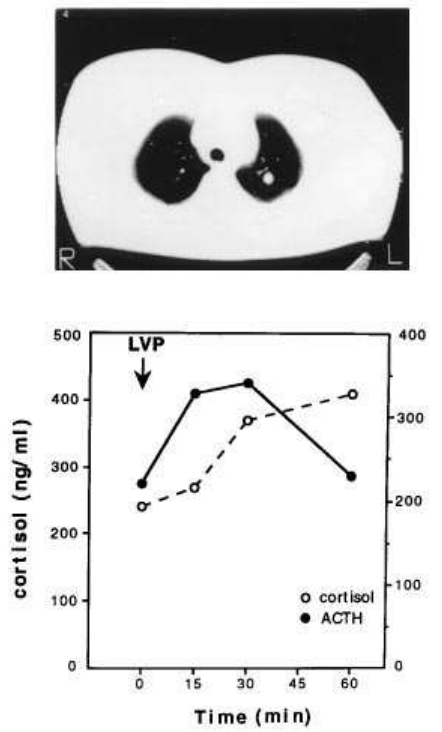

Figure 3. ACTH and cortisol responses to vasopressin administration in two patients with ACTH-secreting bronchial carcinoids. Thorax CT scans showing the small, round-like, welllimited bronchial carcinoids of the patients at the time of diagnosis are shown at the top of the figure. ACTH (measured by bioassay for patient E7, and by RIA for patient E4) and cortisol plasma levels after intramuscular administration of $10 \mathrm{IU}$ of lysine vasopressin are shown at the bottom of the figure. tions, this POMC signal was much stronger in all ACTHsecreting adenomas, and not, or barely (in two of six), detectable in GH- or PRL-secreting adenomas (Fig. $1 A$ ). Signals for $\mathrm{V} 3$ receptor and $\mathrm{CRH}$ receptor genes varied in parallel with those of POMC: 285-nt V3 receptor and 386-nt CRH receptor RT-PCR signals were detected in all normal pituitaries and were more intense in all the ACTH-secreting adenomas except for two tumors which had reduced V3 receptor or CRH receptor gene expression. In comparison, GH- and PRLsecreting adenomas gave no $\mathrm{CRH}$ receptor and only a very faint $\mathrm{V} 3$ receptor signal in three cases.

These results showed that $\mathrm{V} 3$ receptor gene, like the POMC and CRH receptor genes, is indeed preferentially associated with corticotroph cell-containing tissue, whether normal or tumoral. To explore further the apparent link between the expression of these three genes, we extended our study to neuroendocrine tumors of nonpituitary origin.

Bronchial carcinoids. We analyzed 16 bronchial carcinoids, of which 8 secreted ACTH and led to Cushing's syndrome (Cushing +, tumors E1-E8). The expected POMC RT-PCR product and measurable amounts of POMC peptides (above $10^{-2} \mathrm{ng}$ IR-hßend/mg tissue) were present only in the eight tumors responsible for an ectopic ACTH syndrome (Fig. 2). Six of these eight carcinoids (E2-E7) gave high intensity V3 receptor RT-PCR signals identical to those observed in authentic pituitary corticotroph adenomas of Nelson's syndrome (Fig. 2, $N)$. These bronchial carcinoids (E2-E7) were highly differentiated neuroendocrine tumors according to their typical carcinoid features at histological examination and their long disease-free evolution (Table I). In contrast, the two bronchial carcinoids which gave low (E8) or undetectable (E1) V3 receptor RT-PCR signals also had less POMC mRNA and peptide tissue contents, and were highly aggressive tumors with local invasiveness leading rapidly to a fatal outcome (Table I).

Six of these eight bronchial carcinoids had been the cause of the so-called occult ectopic ACTH syndrome with a delay to final diagnosis (after recognition of the hypercortisolism) ranging from 3 to $>20 \mathrm{yr}$ (Table I). Spurious diagnostic pitfalls had led to unwarranted pituitary surgery and/or radiation therapy in two cases (E2 and E7). Retrospective analysis of hormonal investigations in two patients (E4 and E7) showed that both indeed had positive ACTH and cortisol responses to vasopressin administration, before they were given any treatment (Fig. 3). Patient E1 who had no V3 receptor RT-PCR signal in her tumor had not responded to vasopressin administration.

Eight bronchial carcinoids which were not associated with Cushing's syndrome had no detectable POMC peptides and gave no POMC RT-PCR signals. In six of them a V3 receptor RT-PCR signal was detected but was much weaker as compared with those in the ACTH-secreting bronchial carcinoids.

We also studied $\mathrm{CRH}$ receptor gene expression in bronchial carcinoids to assess whether it might serve as another marker of the corticotroph phenotype. However, in contrast with the $\mathrm{V} 3$ receptor, the $\mathrm{CRH}$ receptor was detected in the majority of bronchial carcinoids regardless of their POMC status (Fig. 2).

Finally GPDH RT-PCR signals, taken as an estimate of the cDNA input, showed no major variations between samples, indicating that the intensities of the $\mathrm{V} 3$ receptor, $\mathrm{CRH}$ receptor, and POMC RT-PCR signals did reflect differences in gene expression levels.

Other endocrine tumors. We examined another series of nonpituitary tumors responsible for ectopic ACTH syndrome: two metastases $(\mathrm{Met})$ of neuroendocrine tumors of unknown origin, one metastatic medullary thyroid carcinoma, and two pheochromocytomas. In contrast with bronchial carcinoids, all these tumors, except one pheochromocytoma, were highly aggressive. They were characterized by much lower levels of both V3 receptor and POMC gene expression in comparison with the same ACTH-secreting pituitary adenoma as in Fig. 2 (Fig. $4, N$ ) (note also the longer exposure times of 14 and $8 \mathrm{~h}$ in Fig. 4, compared with 5 and $3 \mathrm{~h}$ in Fig. 2, for V3 receptor and POMC genes, respectively). The highest content in POMC peptides (1 ng IR-hßend/mg tissue) was 1,000-fold lower than the mean observed in the six ACTH-secreting bronchial carcinoids with the highest V3 receptor gene expression (E2-E7, 


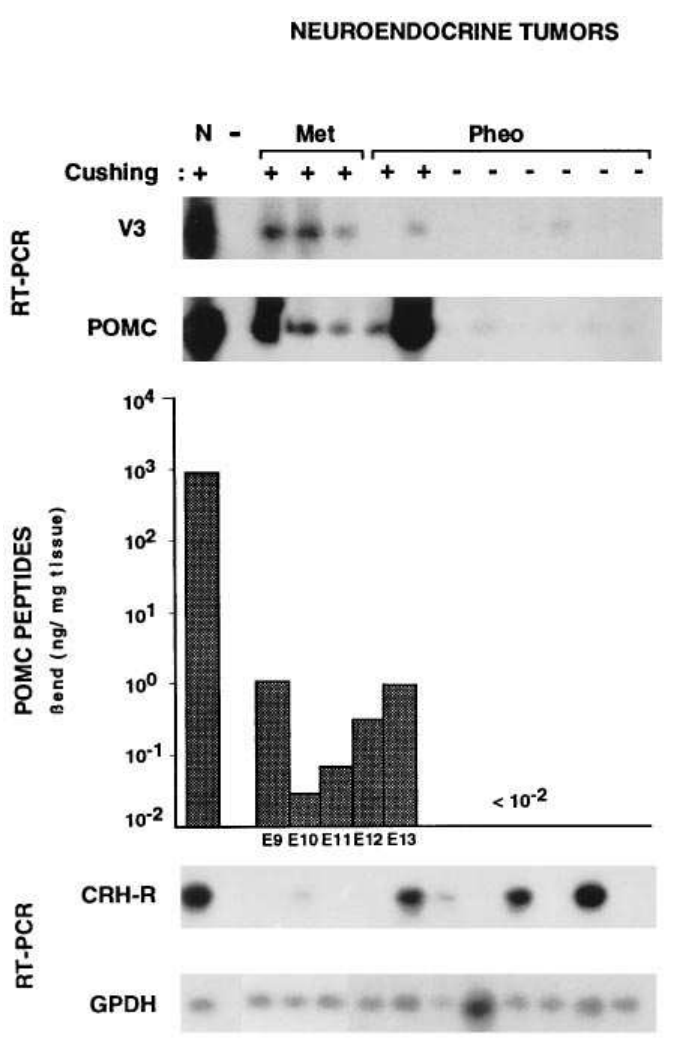

Figure 4. Analysis of the expression of the V3 receptor, POMC, $\mathrm{CRH}$ receptor, and GPDH genes in neuroendocrine tumors of various origins responsible $(+)$ or not $(-)$ for the ectopic ACTH syndrome. Three metastases (Met) of two neuroendocrine tumors of unknown origin and one medullary thyroid carcinoma (from left to right), and eight pheochromocytomas (Pheo) were studied. See legend to Fig. 2. The V3 and POMC blots were overexposed, as indicated by the intense signal given by the same pituitary tumor as in Fig. $2(N)$. Exposure times were 14, 8, 2, and $4 \mathrm{~h}$ for $\mathrm{V} 3$ receptor, POMC, CRH receptor, and GPDH, respectively.

Fig. 2). Yet V3 receptor RT-PCR signals appeared more readily detectable in those tumors which also expressed the POMC gene. Expression of the $\mathrm{CRH}$ receptor was present in most pheochromocytomas, irrespective of their POMC status.
Again, GPDH RT-PCR signals showed no gross variations between samples, except one with high cDNA input but no detectable V3 receptor and barely detectable POMC RT-PCR signals.

Northern blot analysis and S1 nuclease protection assay. To confirm the presence of V3 mRNA and to analyze further its structure, we isolated poly(A) ${ }^{+}$RNA from an ACTHsecreting pituitary adenoma responsible for a case of Nelson's syndrome $(N)$ and two ACTH-secreting bronchial carcinoids (E3 and E2). The RNA was analyzed by Northern blot with a 1.3-kb probe corresponding to most of the $\mathrm{V} 3$ receptor gene coding region. A single $\sim 5.0-\mathrm{kb}$ mRNA was detected in all ACTH-secreting tumors of pituitary or nonpituitary origin (Fig. $5 \mathrm{~A}$ ), as reported previously in normal human pituitary (22).

S1 protection assay revealed the same, unique 149-nt fragment in an ACTH-secreting pituitary adenoma, normal pituitary, and an ACTH-secreting bronchial carcinoid (E3) (Fig. 5 $B$, lanes 1,2 , and 3 ); in contrast no signal was detected in a nonsecreting bronchial carcinoid (Fig. 5 B, lane 4). Quantitatively, these results confirmed the dramatic differences observed by the comparative RT-PCR approach.

In situ hybridization. Tissue distributions of $\mathrm{V} 3$ receptor and POMC mRNAs were analyzed by in situ hybridization in two consecutive sections of one of the ACTH-secreting bronchial carcinoids (E6, Fig. 6). Although the V3 receptor mRNA gave a more homogeneous pattern, both mRNAs had superimposable tissue distributions in the same tumor.

\section{Discussion}

The mechanism of POMC gene transcription in nonpituitary tumors causing ectopic ACTH syndrome is not known: it may be the fortuitous result of a wide and nonspecific genetic turmoil which also picks up the POMC gene or, alternatively, it may be due to the faithful transposition of a more or less complete corticotroph phenotype out of the pituitary limits. To test the second of these two possibilities, we thought that the recently identified V3 vasopressin receptor, the expression of which appears preferentially associated with the pituitary corticotroph cell in humans, was the ideal molecular probe and that the bronchial carcinoids, which often express large amounts of the POMC gene, were the best tumor candidates.

The cloning of the human V3 receptor has completed the
A

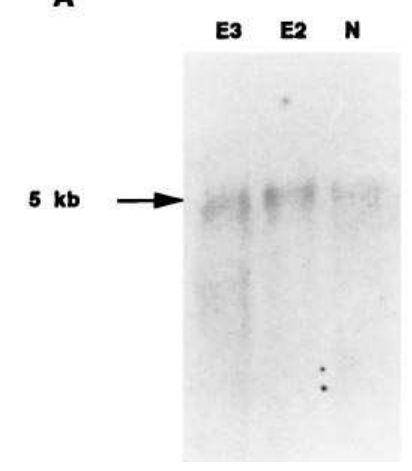

B

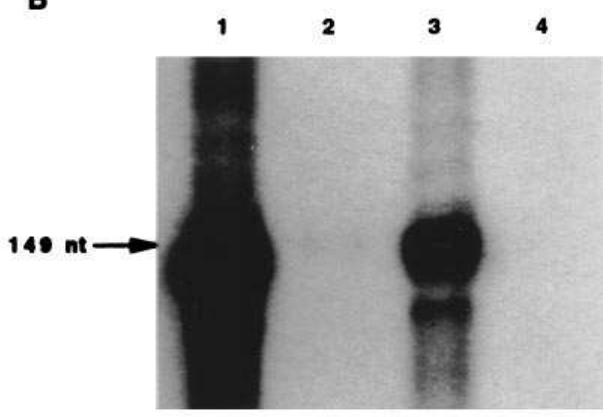

Figure 5. Northern blot analysis $(A)$ and $\mathrm{S} 1$ nuclease protection $(B)$ of $\mathrm{V} 3 \mathrm{mRNA}$. (A) 5 $\mu \mathrm{g}$ poly $(\mathrm{A})^{+}$RNA was separated on $1 \%$ denaturing agarose gel, blotted onto nitrocellulose, and probed with a 1.3-kb random primed human $\mathrm{V} 3 \mathrm{cDNA}$ fragment. The gel was autoradiographed for $6 \mathrm{~d}$ at $-80^{\circ} \mathrm{C}$ with intensifying screens. The signals obtained with RNA from two ACTH-secreting bronchial carcinoids (patients E3 and E2) and one ACTH-secreting pituitary adenoma responsible for a case of Nelson's syndrome $(N)$ are shown. The arrow indicates the 5-kb V3 mRNA. (B) RNA was hybridized for $16 \mathrm{~h}$ at $48^{\circ} \mathrm{C}$ with a V3 genomic single-stranded probe. The S1 nuclease-protected fragments were separated on a $5 \%$ polyacrylamide $/ 7 \mathrm{M}$ urea sequencing gel. The dried gel was autoradiographed for $3 \mathrm{~d}$ at $-80^{\circ} \mathrm{C}$ with one intensifying screen. Lane 1, ACTH-secreting pituitary adenoma (20 $\mu \mathrm{g}$ total RNA); lane 2, normal human pituitary ( $2 \mu \mathrm{g}$ poly (A) $\left.{ }^{+} \mathrm{RNA}\right)$; lane 3, ACTH-secreting bronchial carcinoid (E3, $20 \mu \mathrm{g}$ total RNA); lane 4, nonsecreting bronchial carcinoid (20 $\mu \mathrm{g}$ total RNA). The arrow points to the 149-nt protected fragment. 


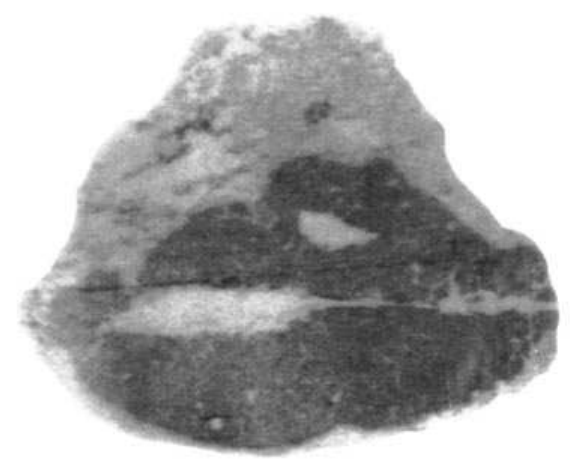

V3 receptor

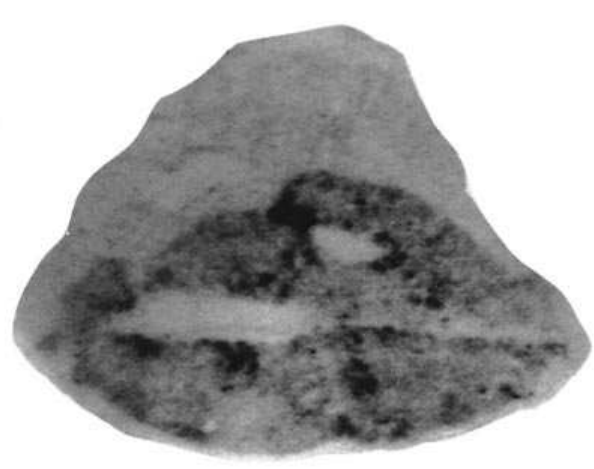

POMC
Figure 6. Autoradiographic localization by in situ hybridization of POMC and $\mathrm{V} 3$ receptor mRNAs in an ACTH-secreting bronchial carcinoid. Consecutive tissue sections of bronchial carcinoid (E6) were hybridized with a $1.3-\mathrm{kb}$ V3 receptor cRNA probe and a POMC cDNA probe and exposed for 14 and $4 \mathrm{~d}$, respectively. long search for the "pituitary-specific" vasopressin receptor $(21,22)$. It belongs to a large and widely distributed subfamily of $\mathrm{G}$ protein-coupled receptors which includes the vascular $\mathrm{V} 1$, the renal $\mathrm{V} 2$, and the oxytocin receptors. The V3 receptor is found mainly, if not exclusively, in anterior pituitary corticotroph cells $(21-24,33)$.

Because Northern blot analysis had revealed extremely low levels of V3 receptor mRNA even in ACTH-secreting pituitary adenomas (21), and because of the scarcity and the small size of most of these tumors, a sensitive method for small quantities of RNA had to be chosen. Our RT-PCR approach was not strictly quantitative. Since its primary purpose was to look for gross differences between series of various types of tumors, the following precautions were taken to allow sound comparisons: the number of cycles always corresponded to the exponential part of the amplified curve, the similarity of the cDNA input was checked by the simultaneous amplification of the internal marker GPDH, the same reference pituitary tumor $(\mathrm{N})$ was used in different experiments, and, finally, a S1 nuclease protection analysis confirmed the results of the RTPCR approach in selected cases.

RNA from all six normal human pituitaries gave a single signal of the expected size, which hybridized with an internal specific probe. It was not surprising that all ACTH-secreting pituitary adenomas of Cushing's disease gave the same-sized signal as normal pituitary. The similarity of the experimental design suggested that the V3 receptor mRNA was in general more abundant in the tumor specimens. Whether this merely reflected a higher concentration of corticotroph cells in the tumor than that in normal pituitary or corresponded to a true overexpression of the V3 receptor gene in tumor cells is unclear. GH and PRL-secreting pituitary adenomas had barely detectable V3 receptor RT-PCR signals; they could correspond either to a minor but genuine property of these nonACTH cells, as suggested by recent data in the rat (23), or to a slight contamination by anterior pituitary corticotrophs since the samples were obtained by the transsphenoidal route. However, contamination is suggested by coexisting POMC signals in RT-PCR tests. Therefore, these results confirmed that in the pituitary V3 receptor gene expression is indeed preferentially associated with the corticotroph cell.

Although the ectopic ACTH syndrome was first recognized in highly malignant tumors including SCCL (4), it has become obvious that it can also be associated with small and indolent tumors, like bronchial carcinoids for example (15). This clinical distinction today finds a molecular correlate with an alternate gene marker of the corticotroph phenotype: assessment of $\mathrm{V} 3$ receptor gene expression in ACTH-producing nonpituitary tumors characterizes the bronchial carcinoids as a particular subset of tumors where both V3 receptor and POMC genes are expressed in a pattern indistinguishable from that in authentic ACTH-secreting pituitary adenomas.

In their typical histological form, bronchial carcinoids are a homogeneous group of tumors with an indolent course and a high degree of neuroendocrine differentiation, as exemplified by their content of specific biochemical markers of secretory granules (40). Also, they contain prohormone convertases PC1 (41) and PC2 (42) which can process various precursors to their bioactive peptide hormones: therefore, peptide hormone content in such tumors is correlated with overall gene expression (6). Some of these tumors express the POMC gene almost as if they were an authentic pituitary corticotroph cell: they use the normal promoter generating only the pituitary-like, 1200nt, POMC mRNA (43); they produce equal if not higher levels of POMC mRNA and POMC peptides $(6,10,44)$; they process the precursor to release large amounts of bioactive ACTH (11). The apparent coordinate expression of two different genes (coding for the V3 receptor and for POMC), which characterize the pituitary corticotroph cell, strengthens the idea that a broad process of corticotroph differentiation is achieved in these nonpituitary tumors.

Bronchial carcinoids can be an endocrinologist's nightmare when they remain occult for many years in patients with Cushing's syndrome (13). Not only are they difficult to locate but they can be highly misleading when they behave like authentic pituitary tumors in their responses to the classical dynamic tests using CRH, metyrapone, or dexamethasone (17). Such patients may be mistakenly subjected to pituitary surgery (18). It is interesting to observe that three of our eight patients with bronchial carcinoids had been diagnosed as having Cushing's disease up to $21 \mathrm{yr}$ before the bronchial tumor was discovered and removed: one had unduly undergone pituitary surgery and the three eventually had bilateral adrenalectomy. In two patients a positive ACTH response to vasopressin administration had been evidently misleading. We understand now that what had been taken as an aberrant response was actually appropriate. Two recent developments contribute to improved investigation of such tumors: inferior petrosal sinus sampling avoids 
the erroneous diagnosis of Cushing's disease (45), and scintigraphic imaging with [ ${ }^{\mathrm{II} I n]-D T P A-p e n t e t r e o t i d e ~ h e l p s ~ t o ~ l o-~}$ cate these bronchial carcinoids which also express somatostatin receptors (46). However, this latter technique is neither specific for neuroendocrine tumors nor always contributive. We expect that scintigraphic imaging with specific V3 ligands will improve their investigation.

The detection of $\mathrm{V} 3$ receptor mRNA in a tissue is in no way proof that it functions. The RT-PCR signal was associated with an apparently normal sized mRNA as assessed by Northern blot and S1 nuclease protection analyses, and in situ hybridization showed a superimposable tissue distribution of V3 and POMC gene expression in ACTH-secreting tumors. However, we were not able to perform the pharmacological studies necessary to demonstrate the function of the V3 receptor. Our in vivo results in two patients suggest that vasopressin receptors in bronchial carcinoids may be functionally coupled to ACTH secretion (47) like in pituitary corticotroph cells. These observations suggest that new pharmacological investigations with specific V3 receptor agonists might help unravel and even manipulate this peculiar ACTH hypersecretory syndrome.

The CRH receptor was specifically associated with the corticotroph cells in pituitary. It was much more widely distributed than the V3 receptor in nonpituitary tumors. Particularly, $\mathrm{CRH}$ receptors were found equally in ACTH nonproducing bronchial carcinoids, in the nonendocrine bronchial tumors (data not shown), and in pheochromocytomas. This distribution is in agreement with the known widespread distribution of $\mathrm{CRH}$ and $\mathrm{CRH}$ actions in endocrine and nonendocrine tissues $(48,49)$. It is thus a much less specific marker of the corticotroph phenotype than the $\mathrm{V} 3$ receptor.

Some bronchial carcinoids are histologically described as atypical. They are considered as intermediary between typical carcinoids and the SCCL (50). In comparison with the former they are more aggressive tumors that have lost some of their neuroendocrine characteristics. The two patients with ACTHsecreting bronchial carcinoids which presented the weakest V3 receptor gene expression (E1 and E8) had tumors, classified as atypical which were invasive at surgery, and indeed led to a rapid and fatal outcome.

The functional or causal role for the V3 receptor in ACTHsecreting nonpituitary tumors is not known. If it contributes to an increase in POMC gene expression and/or ACTH secretion, it may act through simple overexpression of a wild-type receptor, as shown recently in experimental models for adrenergic receptors in the heart (51), through expression of a constitutively activated receptor as shown in human pathological states with lutenizing hormone and thyroid-stimulating hormone receptors (52), or through chronic receptor stimulation under the auto- or paracrine action of locally produced vasopressin $(53,54)$. Alternatively, expression of (a) common transactivating factor(s) involved in the tissue-specific expression of both the V3 and the POMC genes in pituitary corticotroph cells may cause ectopic ACTH secretion, at least in this newly characterized subset on nonpituitary tumors. Two factors have been identified recently which seem to be involved in tissuespecific POMC gene expression in the pituitary, Cute (55) and Brn 3.0 (56). Further studies will examine their possible role in ectopic ACTH syndrome.

There have been few studies of ACTH-secreting human SCCL cell lines. No gross POMC gene rearrangement has been found (12) and therefore the role of a trans-activating factor has been presumed. This view is reinforced by the recent demonstration that a heterologous reporter gene fused to the human POMC gene promoter region can be specifically transcribed in the DMS-79 SCCL cell line (57). There is evidence for abnormal function of glucocorticoid receptors in such cell lines although it does not explain why POMC gene expression is initiated (58). The SCCL appear quite different from the bronchial carcinoid tumors: they are highly malignant, display fewer biochemical markers of neuroendocrine differentiation (39), produce low levels and altered molecular forms of POMC mRNA (43) and POMC peptides $(11,59)$, and, as shown here in poorly differentiated and aggressive neuroendocrine tumors, rarely and barely express the V3 receptor gene. Therefore, it is tempting to speculate that a different molecular mechanism acting in an aberrant (nonpituitarylike) manner induces ectopic POMC gene transcription in this different subtype of tumors.

Comparative analysis of V3 receptor gene expression was instrumental to assess the corticotroph phenotype of tumors responsible for ectopic ACTH syndrome. It reveals that this syndrome is actually made of two different entities: when it is due to indolent and highly differentiated tumors, with the highest levels of $\mathrm{V} 3$ receptor, like bronchial carcinoids, it might be best called ectopic corticotroph syndrome; in contrast, when it is due to aggressive, poorly differentiated tumors with much lower $\mathrm{V} 3$ receptor, it might be best called aberrant ACTH secretion syndrome.

\section{Acknowledgments}

We are greatly indebted to Drs. P. Derome, F. Peillon, Ph. Levasseur, J.D. Lalau, A. Grimaldi, J.-L. de Gennes, F. Dairou, Ph. Dartevelle, and E. Dulmet for helping us collect pituitary and nonpituitary tumors, and to Mrs. M. Le Scouarnec for her expert secretarial assistance.

This work was supported in part by INSERM Contrat Jeune Formation 9208, l'Association pour la Recherche contre le Cancer (contrat 6501), and la Fondation de France.

\section{References}

1. Iacangelo, A., H.U. Affolter, L. Eidel, E. Herbert, and M. Grimes. 1986. Bovine chromogranin A: its sequence and the distribution of its messenger RNA in endocrine tissues. Nature (Lond.). 323:82-85.

2. Vieau, D., C.G. Linard, M. Mbikay, F. Lenne, M. Chretien, J.P. Luton, and X. Bertagna. 1992. Expression of the neuroendocrine cell marker 7B2 in human ACTH secreting tumors. Clin. Endocrinol. 36:597-603.

3. Seidah, N.G., R. Day, M. Marcinkiewicz, S. Benjannet, and M. Chretien. 1991. Mammalian neural and endocrine pro-protein and pro-hormone convertases belonging to the subtilisin family of serine proteinases. Enzyme (Basel). 45:271-284.

4. Liddle, G.W., W.E. Nicholson, D.P. Island, D.N. Orth, L. Abe, and S.C. Lowder. 1969. Clinical and laboratory studies of ectopic humoral syndromes. Recent Prog. Horm. Res. 25:283-314.

5. Rees, L.H., and J.G. Ratcliffe. 1974. Ectopic hormone production by non-endocrine tumours. Clin. Endocrinol. 3:263-299.

6. de Keyzer, Y., X. Bertagna, F. Lenne, F. Girard, J.P. Luton, and A. Kahn. 1985. Altered proopiomelanocortin gene expression in ACTH producing nonpituitary tumors. J. Clin. Invest. 76:1892-1898.

7. Vieau, D., J.F. Massias, F. Girard, J.P. Luton, and X. Bertagna. 1989. Corticotrophin-like intermediary lobe peptide as a marker of alternate proopiomelanocortin processing in ACTH-producing non-pituitary tumours. Clin. Endocrinol. 31:691-700.

8. De Bold, C.R., E.E. Mufson, J.K. Menefee, and D.N. Orth. 1988. Proopiomelanocortin gene expression in a pheochromocytoma using upstream transcription initiation sites. Biochem. Biophys. Res. Commun. 155:895-900.

9. Clark, A.J.L., P.M. Lavender, G.M. Besser, and L.H. Rees. 1988. Proopiomelanocortin mRNA size heterogeneity in ACTH-dependent Cushing's syndrome. J. Mol. Endocrinol. 2:3-9. 
10. Lacaze-Masmonteil, T., Y. De Keyzer, J.P. Luton, A. Kahn, and X. Bertagna. 1987. Characterization of proopiomelanocortin transcripts in human non-pituitary tissues. Proc. Natl. Acad. Sci. USA. 84:7261-7265.

11. Bertagna, X. 1994. Proopiomelanocortin-derived peptides. In Endocrinology and Metabolism Clinics of North America: Cushing's Syndrome. D.C. Aron and J.B. Tyrrell, editors. W.B. Saunders Co., Philadelphia, PA. 467-485.

12. Israel, A., and S.N. Cohen. 1985 . Hormonally mediated negative regulation of human proopiomelanocortin gene expression after transfection into mouse L cells. Mol. Cell. Biol. 5:2443-2453.

13. Kreisberg, R. 1994. Half a loaF. N. Engl. J. Med. 330:1295-1299.

14. Doppman, J.L. 1992. The search for occult ectopic ACTH-producing tumors. Endocrinologist. 2:41-46.

15. Mason, A.M.S., J.G. Ratcliffe, R.M. Buckle, and A.S. Mason. 1972. ACTH secretion by bronchial carcinoid tumours. Clin. Endocrinol. 1:3-25.

16. Findling, J.W., and J.B. Tyrrel. 1986. Occult ectopic secretion of corticotropin. Arch. Intern. Med. 146:929-933.

17. Malchoff, C.D., D.N.Orth, C. Abboud, J.A. Carney, P.C. Pairolero, and R.M. Carey. 1988. Ectopic ACTH syndrome caused by a bronchial carcinoid tumor responsive to dexamethasone, metyrapone, and corticotropin-releasing factor. Am. J. Med. 84:760-764.

18. Federman, D.F., and E.J. Mark. 1981. Persistence of Cushing's syndrome after hypophysectomy. N. Engl. J. Med. 305:1637-1643.

19. Jard, S. 1985. Vasopressin receptors. Front. Horm. Res. 13:89-104.

20. Antoni, F. 1984. Novel ligand specificity of pituitary vasopressin receptors in the rat. Neuroendocrinology. 39:186-188.

21. de Keyzer, Y., C. Auzan, F. Lenne, C. Beldjord, M. Thibonnier, X. Bertagna, and E. Clauser. 1994. Cloning and characterization of the human V3 pituitary vasopressin receptor. FEBS Lett. 356:215-220.

22. Sugimoto, T., M. Saito, S. Mochizuki, Y. Watanabe, S. Hashimoto, and H. Kawashima. 1994. Molecular cloning and functional expression of a cDNA encoding the human V1b vasopressin receptor. J. Biol. Chem. 269:27088-27092.

23. Lolait, S.J., A.-M. O'Carroll, L.C. Mahan, C.C. Felder, D.C. Button, W. Scott Young III, E. Mezey, and M.J. Brownstein. 1995. Extrapituitary expression of the rat V1b vasopressin receptor gene. Proc. Natl. Acad. Sci. USA. 92: 6783-6787.

24. Saito, M., T. Sugimoto, A. Tahara, and H. Kawashima. 1995. Molecular cloning and characterization of rat V1b vasopressin receptor: evidence for its expression in extra-pituitary tissues. Biochem. Biophys. Res. Commun. 212: 751-757.

25. Morel, A., A.M. O'Carroll, M.J. Brownstein, and S.J. Lolait. 1992. Molecular cloning and expression of a rat V1a arginine vasopressin receptor. $\mathrm{Na}$ ture (Lond.). 356:523-526.

26. Lolait, S.J., A.M. O'Carroll, O.W. McBride, M. Konig, A. Morel, and M.J. Brownstein. 1992. Cloning and characterization of a vasopressin V2 receptor and possible link to nephrogenic diabetes insipidus. Nature (Lond.). 357: 336-339.

27. Birnbaumer, M., A. Seibold, S. Gilbert, J. Ishido, C. Barberis, A. Antaramian, P. Brabet, and W. Rosenthal. 1992. Molecular cloning of the receptor of human antidiuretic hormone. Nature (Lond.). 357:333-335.

28. Kimura, T., O. Tanazawa, K. Mori, M.J. Brownstein, and H. Okayama. 1992. Structure and expression of a human oxytocin receptor. Nature (Lond.). 356:526-529.

29. Mahlmann, S., W. Meyerhof, H. Hausmann, J. Heierhorst, C. Schönrock, H. Zwiers, K. Lederis, and D. Richter. 1994. Structure, function, and phylogeny of [Arg8] vasotocin receptors from teleost fish and toad. Proc. Natl. Acad. Sci. USA. 91:1342-1345.

30. Thibonnier, M., C. Auzan, Z. Madhun, P. Wilkins, L. Mattera-Berti, and E. Clauser. 1994. Molecular cloning, sequencing, and functional expression of a cDNA encoding the human V1a vasopressin receptor. J. Biol. Chem. 269:33043310 .

31. Antoni, F.A. 1988. Receptors mediating the CRH effects of vasopressin and oxytocin. Ann. NY Acad. Sci. 512:195-204.

32. Jard, S., G. Gaillard, G. Guillon, J. Marie, P. Schoenenberg, A.F. Muller, M. Manning, and W.H. Sawyer. 1986. Vasopressin antagonists allow demonstration of a novel type of vasopressin receptor in the rat adenohypophysis. Mol. Pharmacol. 30:171-177.

33. Du Pasquier, D., F. Loup, M. Dubois-Dauphin, J.J. Dreifuss, and E. Tribollet. 1991. Binding sites for vasopressin in the human pituitary are associated with corticotrophs and may differ from other known vasopressin receptors. $J$. Neuroendocrinol. 3:237-247.

34. Luton, J.P., J.A. Mahoudeau, P. Bouchard, P. Thieblot, M. Hautecouverture, D. Simon, M.H Laudsat, Y. Touitou, and H. Bricaire. 1979. Treatment of Cushing's disease by Op'DDD. Survey of 62 cases. N. Engl. J. Med. 300:459464.

35. Raux, M.C., M. Binoux, J.P. Luton, M. Gourmelen, and F. Girard. 1975. Studies of ACTH secretion control in 116 cases of Cushing's syndrome. J. Clin. Endocrinol. \& Metab. 40:186-197.

36. Bertagna, X., W.E. Nicholson, G.D. Sorenson, O.S. Pettengill, C.D. Mount, and D.N. Orth. 1978. Corticotropin, lipotropin, and $\beta$-endorphin production by a human nonpituitary tumor in tissue culture: evidence for a com- mon precursor. Proc. Natl. Acad. Sci. USA. 75:5160-5164.

37. Chirgwin, J.M., A.E. Przybyla, R.J. MacDonald, and W.J. Rutter. 1979. Isolation of biologically active ribonucleic acid from sources enriched in ribonuclease. Biochemistry. 18:5294-5299.

38. Sambrook, J., E.F. Fritsch, and T. Maniatis. 1989. Molecular Cloning: A Laboratory Manual. Cold Spring Harbor Laboratory, Cold Spring Harbor, NY.

39. Lefevre, H., S. Jegou, P. Leroux, M. Dero, H. Vaudry, and J.M. Kuhn. 1995. Characterization of the somatostatin receptor subtype in a bronchial carcinoid tumor responsible for Cushing's syndrome. J. Clin. Endocrinol. \& Metab. 80:1423-1428

40. Vieau, D., A. Rojas-Miranda, J.M. Verley, F. Lenne, and X. Bertagna 1991. The secretory granule peptides 7B2 and CCB are sensitive biochemical markers of neuro-endocrine bronchial tumors in man. Clin. Endocrinol. 35:319325 .

41. Creemers, J., A. Roebroek, and W. Van de Ven. 1992. Expression in human lung tumor cells of the proprotein processing enzyme PC1/PC3: cloning and primary sequence of a 5Kb cDNA. FEBS Lett. 300:82-88.

42. Vieau, D., N.G. Seidah, M. Chrétien, and X. Bertagna. 1994. Expression of the prohormone convertase PC2 correlates with the presence of CLIP in human ACTH secreting tumors. J. Clin. Endocrinol. \& Metab. 79:1503-1509.

43. de Keyzer, Y., X. Bertagna, J.P. Luton, and A. Kahn. 1989. Variable modes of proopiomelanocortin gene transcription in human tumors. Mol. Endocrinol. 3:215-223.

44. Texier, P.L., Y. de Keyzer, R. Lacave, D. Vieau, F. Lenne, A. RojasMiranda, J.M. Verley, J.P. Luton, A. Kahn, and X. Bertagna. 1991. Proopiomelanocortin gene expression in normal and tumoral human lung. J. Clin. Endocrinol. \& Metab. 73:414-420.

45. Findling, J.W., M.E. Kehoe, J.L. Shaker, and H. Raff. 1991. Routine inferior petrosal sinus sampling in the differential diagnosis of adrenocorticotropin (ACTH)-dependent Cushing's syndrome: early recognition of the occult ectopic ACTH syndrome. J. Clin. Endocrinol. \& Metab. 73:408-413.

46. Phlipponneau, M., M. Nocaudie, J. Epelbaum, Y. de Keyzer, J.D. Lalau, X. Marchandise, and X. Bertagna. 1994. Somatostatin analogs for the localization and preoperative treatment of an ACTH-secreting bronchial carcinoid tumor. J. Clin. Endocrinol. \& Metab. 78:20-24.

47. Suda, T., F. Tozawa, I. Dobashi, N. Horiba, N. Ohmori, and M. Yamakado. 1993. Corticotropin-releasing hormone, proopiomelanocortin, and glucocorticoid receptor gene expression in adrenocorticotropin-producing tumors in vitro. J. Clin. Invest. 92:2790-2795.

48. Muglia, L.J., N.A. Jenkins, D.J. Gilbert, N.G. Copeland, and J.A. Majzoub. 1994. Expression of the mouse corticotropin-releasing hormone gene in vivo and targeted inactivation in embryonic stem cells. J. Clin. Invest. 93:20662072.

49. Orth, D. 1992. Corticotropin-releasing hormone in humans. Endocr. Rev. 13:164-191.

50. Warren, W.H., V.E. Gould, L.P. Fabre, C.F. Kittle, and V.A. Memoli. 1985. Neuroendocrine neoplasms of the bronchopulmonary tract. A classification of the spectrum of carcinoid to small cell carcinoma and intervening variants. J. Thorac. Cardiovasc. Surg. 89:819-825.

51. Milano, C.A., L.F. Allen, H.A. Rockman, P.C. Dolber, T.R. McMinn, K.R. Chien, T.D. Johnson, R.A. Bond, and R. Lefkowitz. 1994. Enhanced myocardial function in transgenic mice overexpressing the Béta2-adrenergic receptor. Science (Wash. DC). 264:582-586.

52. Parma, J., L. Duprez, J. Van Sande, P. Cochaux, C. Gervy, J. Mockel, J. Dumont, and G. Vassart. 1993. Somatic mutations in the thyrotropin receptor gene cause hyperfunctioning thyroid adenomas. Nature (Lond.). 365:649-651.

53. Utiger, R.D. 1966. Inappropriate antidiuresis and carcinoma of the lung: detection of arginine vasopressin in tumor extracts by immunoassay. J. Clin. Endocrinol. \& Metab. 26:970-974.

54. Becker, K.L. 1984. Historical perspective on the pulmonary endocrine cell. In The Endocrine Lung in Health and Disease. K.L. Becker and A.F. Gazdar, editors. W.B. Saunders Company, Philadelphia. 156-161.

55. Therrien, M., and J. Drouin. 1993. Cell-specific helix-loop-helix factor required for pituitary expression of the pro-opiomelanocortin gene. Mol. Cell. Biol. 130:2342-2353.

56. Gerrero, M.R., R.J. McEvilly, E. Turner, C.R. Lin, S. O'Connell, K.J. Jenne, M.V. Hobbs, and M.G. Rosenfeld. 1993. Brn-3.0: a POU-domain protein expressed in the sensory, immune, and endocrine systems that functions on elements distinct from known octamer motifs. Proc. Natl. Acad. Sci. USA. 90: 10841-10845.

57. Picon, A., M. Leblond-Francillard, M.L. Raffin-Sanson, F. Lenne, X. Bertagna, and Y. de Keyzer. 1995. Functional analysis of the human proopiomelanocortin promoter in the small cell lung carcinoma cell line DMS 79. $J$. Mol. Endocrinol. 15:187-194.

58. White, A., and A. Clark. 1993. The cellular and molecular basis of the ectopic ACTH syndrome. Clin. Endocrinol. 39:131-142.

59. Stewart, P.M., S. Gibson, S.R. Crosby, R. Penn, R. Holder, D. Ferry, N Thatcher, P. Phillips, D.R. London, and A. White. 1994. ACTH precursors characterize the ectopic ACTH syndrome. Clin. Endocrinol. 40:199-204. 